\title{
Book Reviews: Tribal Cultural Resource Management: The Full Circle to Stewardship
}

Robert Cast

Unknown

Follow this and additional works at: https://scholarworks.sfasu.edu/ita

Part of the American Material Culture Commons, Archaeological Anthropology Commons, Environmental Studies Commons, Other American Studies Commons, Other Arts and Humanities Commons, Other History of Art, Architecture, and Archaeology Commons, and the United States History Commons

Tell us how this article helped you.

This Article is brought to you for free and open access by the Center for Regional Heritage Research at SFA ScholarWorks. It has been accepted for inclusion in Index of Texas Archaeology: Open Access Gray Literature from the Lone Star State by an authorized editor of SFA ScholarWorks. For more information, please contact cdsscholarworks@sfasu.edu. 


\section{Book Reviews: Tribal Cultural Resource Management: The Full Circle to}

Stewardship

\section{Creative Commons License}

\section{(c) (1) (8)}

This work is licensed under a Creative Commons Attribution-NonCommercial 4.0 International License 


\section{Book Reviews}

\section{Tribal Cultural Resource Management: The Full Circle to Stewardship,}

by Darby C. Stapp and Michael S. Burney, 2002. AltaMira Press, Walnut Creek, California. xiv + 246 pp.

\section{Reviewed by Robert Cast, Caddo Nation Historic Preservation Officer}

With only ten chapters, Tribal Cultural Resource Management provides model strategies of what it takes to properly "manage" cultural resources. Although it is geared toward tribal governments and creating the right combination of preservation and protection of their culture, don't let the title fool you, this book is for any person who has a responsibility as a land manager. Those currently involved in Cultural Resource Management (CRM) work should give this book a close read. Off hand, I can think of several federal agencies, especially those operating without Cultural Resource Management Plans, who could truly benefit from following the practical strategies outlined in this readable and informal book.

The premise of the book revolves around Stapp and Burney's definition of Cultural Resource Stewardship: "Cultural resource stewardship means preserving, protecting, and ensuring that cultural resources are accessible, as appropriate, for present and future generations, especially descendant communities" (p. 169). The book provides numerous insights, anecdotes, examples, and point-by-point discussions of many different aspects of tribal cultural resource management, from a detailed case study, to setting up a Tribal Historic Preservation Office, to examples of form letters to initiate discussions with agencies.

Stapp and Burney (both archeologists, by the way) share over 25 years of experience working with federal agencies, Indian tribes, and the bureaucracy currently known as CRM. Through the years, they have worked closely with several tribal governments, but the focus is based on their long working relationship with the Confederated Tribes of the Umatilla, and in helping them develop a preservation program along with training tribal members to actively manage the program and the resources of importance to the tribe. As the Tribal Historic Preservation Officer for the Caddo Nation of Oklahoma, I am well aware of the many pitfalls, obstacles, and truly rewarding experiences that working with a tribal government provides.

Part I, Tracing the Roots of Tribal Cultural Resource Management (Chapters 1-5) not only outlines the history of CRM, but provides this from a unique and oftentimes overlooked perspective: how it has involved American Indians over the years. They review current definitions of what CRM is from archeological and anthropological perspectives, then clarify them in terms of certain underlying themes related to their consultations in working with tribal governments. They then briefly discuss the relationship of American Indians to archeology and anthropology from 1492 to the present. The final chapter in Part I provides an overview of their involvement with the Cultural Resource Protection Program of the Confederated Tribes of the Umatilla Indian Reservation.

Part II (Implementing A Tribal Cultural Resource Management Agenda) focuses on issues 
related to tribal cultural resource management. Chapters 6-9 provide insight into a number of key cultural resource management ingredients: setting up a tribal historic preservation office; consultation; a discussion of cultural landscapes and how they relate to current cultural resource management practice; and a discussion of shifts needed from mere management of, to the stewardship of, cultural resources.

Part III, "The Fruits of Synergy", discusses the process of "synergy" and relates it directly to all other concepts of CRM, especially consultation. Synergy is: "people gathering, sharing ideas, looking for solutions, and coming up with better answers collectively than any of them could have developed individually" (p. 185). This should be what consultation entails and tries to accomplish. In this chapter, the authors' present four key goals they believe need to be achieved to meet the needs of American Indians and cultural resource management in general. They are:

- Ensure that federal agencies comply with cultural resource regulations;

- Increase public awareness of and appreciation for cultural resources;

- Foster the relationship among American Indians, archeologists, anthropologists, and others; and

- Keep the tribal cultural resource management movement going.

Tribal Cultural Resource Management has three basic themes: First, “...cultural resource management is more about people than about places and artifacts. While this concept might seem obvious, we will show that as the profession developed, this concept got lost. At some point archeologists forgot that sites and places were still important to living peoples. Archeological sites were the remains of people long gone, and it was the professional's job to bring the lost cultures back to life. Today, we have come to realize that many of the places and resources are ancestral to peoples living today and important for their cultural continuity" (p. 9).

Second, they discuss the paradigm of "cultural resource stewardship" and compare it to CRM. Stapp and Burney suggest that CRM focus less on what certain "sites" need protecting but more on the natural and cultural aspects of management. Hence, they advocate a "stewardship" approach, one that aims to protect both cultural and natural landscapes that have importance and uses to American Indian's past, present, and future use. The dilemma in recognizing that American Indians need certain places for their continued cultural identity does not coincide with the "mitigation" or "data recovery" philosophy of archeology. They realize that too much focus and credence has been placed on what the archeological record can tell us about the past without addressing the present living people's needs for cultural continuity. As a result, American Indians and their sacred places have been adversely impacted because these "mitigation" procedures have either altered or entirely taken away many of those very qualities (whether natural or cultural) that made these sacred places to them in the first place. Stewardship, therefore, must not only recognize the unique connection that American Indians have with the natural and cultural landscape but also openly encourage this relationship. According to Stapp and Burney, federal agencies in charge of managing lands should be more aware of the need for American Indians to actively promote their religion and cultural identity by providing them access to natural and cultural landscapes that they consider important.

Their final recurring theme "is that people who care about cultural resources must be involved if the resources are going to be preserved, protected, and made accessible."

Chapter 7 is one of the most beneficial in the book. It deals with the concept of consultation and "The Cornerstone of Tribal Resource Management" (p. 119). Stapp and Burney state that: "Consultation is an enhanced form of communication which emphasizes trust, respect, and shared responsibility. It is an open and free exchange of information and opinion among parties which leads to a mutual understanding and comprehension. Consultation is integral to a deliberative process which results in effective collaboration and informed decision making." 
Too often, tribal governments are consulted after a federal undertaking has already occurred or all the archeological work has been completed. These governments thus have no opportunity to be involved in "collaboration" when decisions have already been made. Moreover, this covert slight continues to foster a lack of respect of the tribal governments for the agencies they work with and vice versa. As partners in the decision-making process, tribal governments have a voice at the table and can share their specific concerns prior to decisions being made.

Anyone in the field of CRM, whether as a private archeological contractor hired to do surveys for a federal agency, a land manager for a federal or state agency, a State Historic Preservation Officer (SHPO), or a Tribal Historic Preservation Officer, knows that the field of CRM is changing shape. Tribal Partnership programs, Programmatic Agreements, and federal laws requiring the participation of tribal governments continue to alter the face of what CRM will become in the future. The key to what it will become involves the active participation of tribal governments as coordinators, participants, and equal voices at a consultation table that has long been run by bureaucrats, archeologists, project planners, and others with little knowledge or concern for tribal beliefs and tribal cultural preservation issues. As the face of CRM changes, so will the many issues of concern to American Indians, such as religious freedom, sovereignty, cultural continuity, and cultural and economic prosperity.

Recently, the Caddo Nation of Oklahoma's Cultural Preservation Office received notice that the National Park Service had approved our 101(d)(2) NHPA proposal. This approval was two years in the making, and at the time of the publication of this book had not yet been approved. We are excited to now be added to the list of those tribal historic preservation offices that have made a firm commitment to protecting, preserving, and participating in this thing we now know as CRM. We are the first Indian tribe in the state of Oklahoma to assume such duties. Many people, including experts in the field, said that our proposal would not be accepted due to the fact that the definition of "tribal lands" according to NHPA only includes "lands within the exterior boundaries of a reservation" and that there are basically few lands that fall within that definition in the state of Oklahoma. However, our argument for the approval of the proposal proved acceptable and the Caddo Nation can now take control and manage resources that before were at the decision and discretion of the SHPO. The approval of this proposal is not merely part of a solution to a CRM issue, but in great part further defines the Caddo Nation, their resiliency, their beliefs, their sovereignty, and their need for connecting their present people to their past history. Although I am just along for the ride, I can plainly see that the Caddo Nation is well on their way to what this unique book calls "the full circle of stewardship." 


\section{Order Form}

\section{Back Issues of Caddoan Archeology Newsletter and Caddoan Archeology Journal}

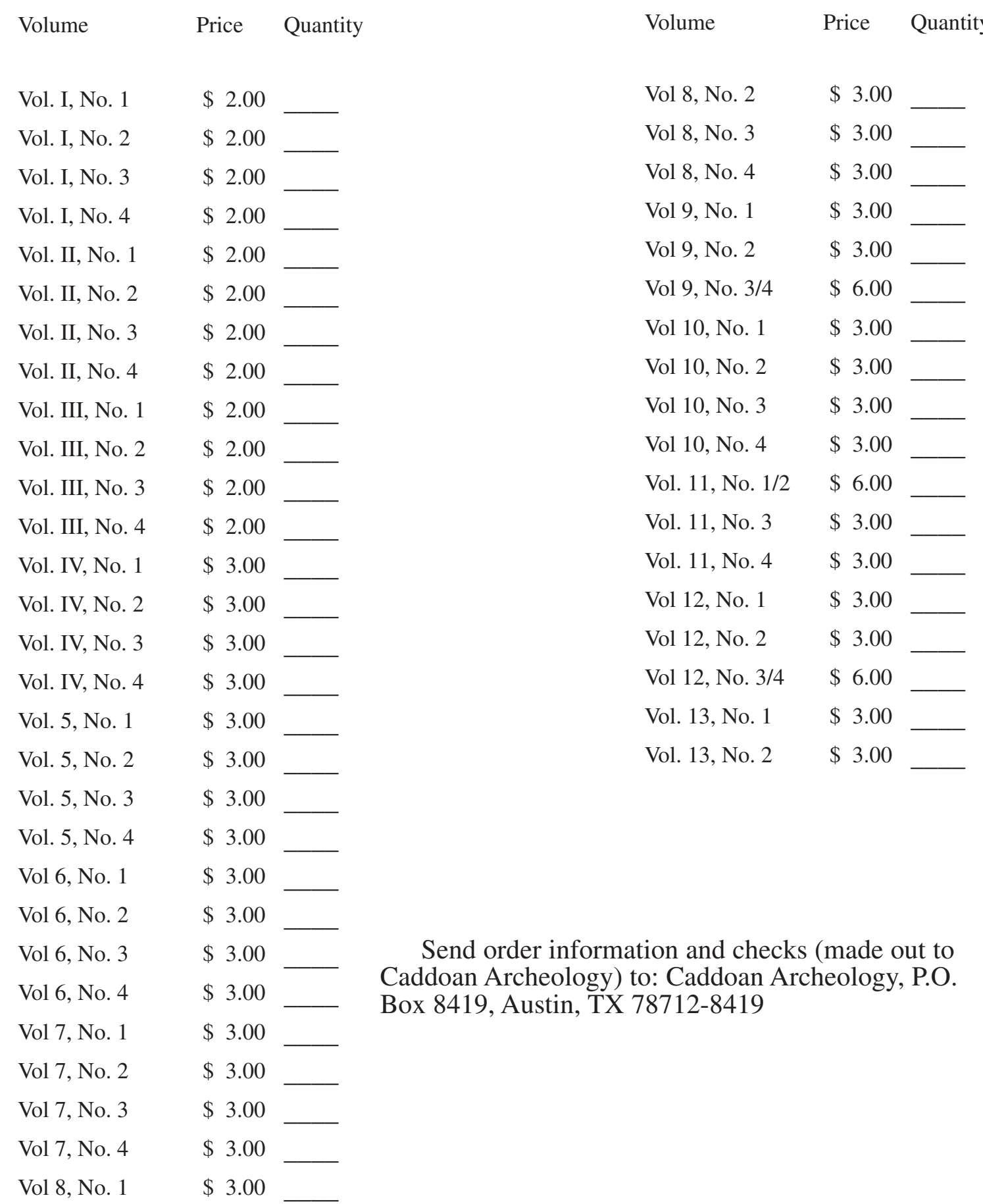

Vol. 5, No. 3

Vol. 5 , No. 4

Vol 6, No. 1

Vol 6, No. 2

Vol 6, No. 3

Vol 6, No. 4

Vol 7, No. 1

Vol 7, No. 2

Vol 7, No. 3

Vol 7, No. 4

Vol 8, No. 1 


\section{Renewal Notice for Volume 14}

Please renew my subscription for Volume 14 of Caddoan Archeology. I have enclosed a check or money order in the amount of $\$ 20.00$, made out to Caddoan Archeology.

Name:

Address:

Telephone:

E-mail:

Please send this form and payment to:

$\$ 3.00$

$\$ 3.00$

$\$ 3.00$

$\$ 3.00$

$\$ 3.00$

$\$ 3.00$

$\$ 3.00$

$\$ 3.00$

$\$ 3.00$

$\$ 3.00$

$\$ 3.00$
Caddoan Archeology Journal

P.O. Box 8419

Austin, Texas 78712-8419 